\title{
Development of the Algae Flora of the Middle Sangzor River under the Influence of Environmental Factors
}

\author{
Z. A. Ismatova \\ Associated Professor Tashkent State Pedagogical University
}

\begin{abstract}
BSTRACT: This article discusses the study of algae flora of the Sangzor River during 2009-2017 and the algal observations made during the four seasons of the year from the observation points identified, as well as algal samples and other data. During the collection of algal samples, water and air temperature, river width and depth, water clarity and color, flow rate, as well as sources of pollution, the amount of oxygen in the water and the $\mathrm{pH}$ of the water were taken into account.
\end{abstract}

EY WORDS: Algae flora, Sangzor River, river width, water clarity, flow rate, sources of pollution, oxygen, Chumkar, Molguzar, Cyanophyta-56, Rhodophyta-2, Xanthopyta-7, Chrysophyta-2, Bacillariophyta-355, Euglenophyta-15.

\section{NTRODUCTION}

In the process of studying the algae flora of the Sangzor River, which has a total length of $110 \mathrm{~km}$, starting from the Chumkar and Molguzar mountains, we divided the river into upper, middle and lower parts according to geomorphological features. To collect algal samples along the river streams, 11 observation points were marked on the map (map of the Sangzor River (Figure 1)).
An important component of water is mineral salts or biogenic elements (dissolved and insoluble organic matter), accumulated organo-mineral compounds. The chemical properties of river water depend on its sources of saturation and the hydrobiological regime that occurs in it. The conditions of the catchment area and local climatic factors play an important role in assessing the chemical condition of the river. 


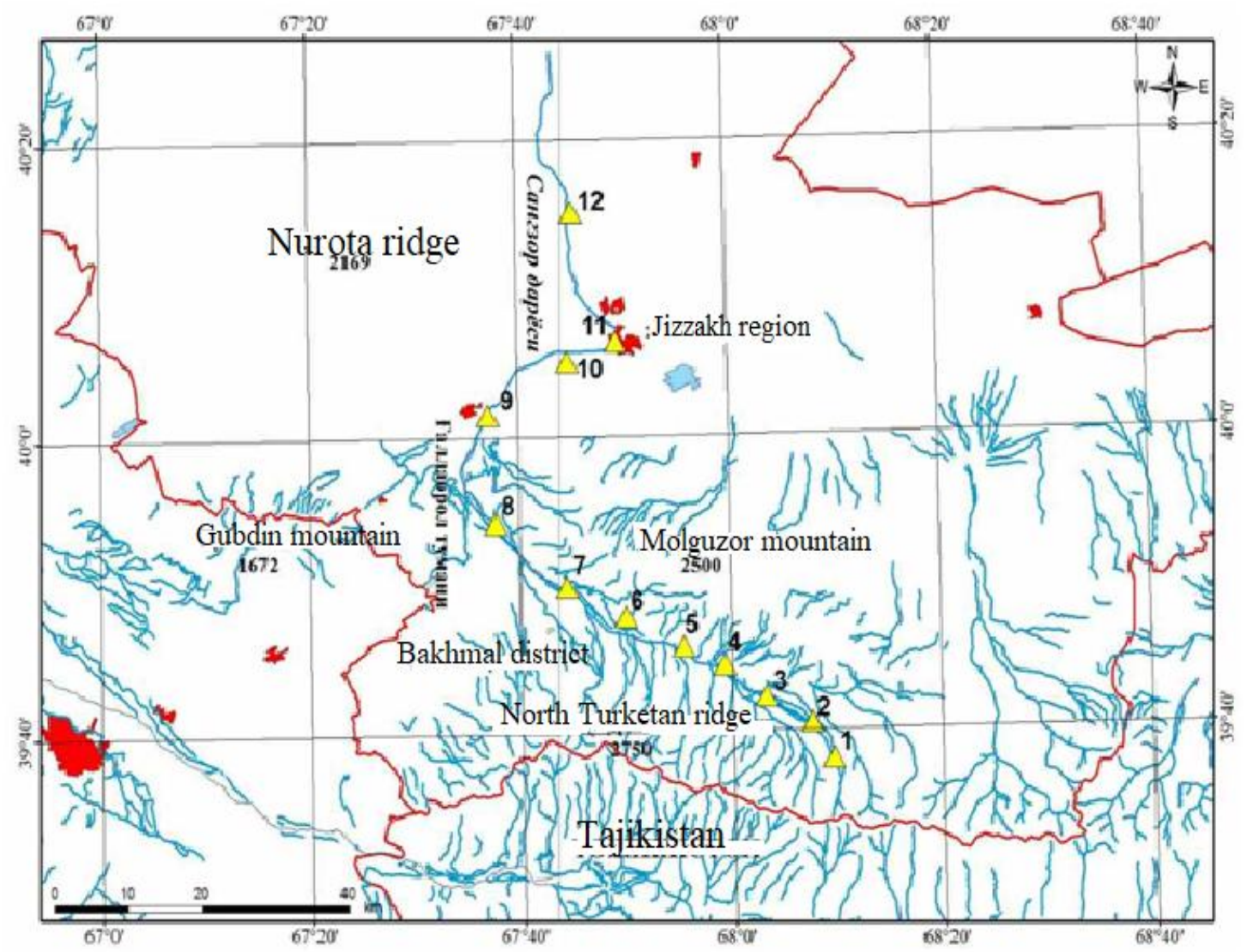

Figure 1. Map-scheme of the Sangzor river:

$\Delta$ - observation points. 1-KN - Zaamin State Reserve; 2-KN - Muzbuloq; 3-KN - Qirq; 4-KN - Jadik; 5-KN - Sutlibuloq; 6$\mathrm{KN}$ - Udamali; 7-KN - Chuqulloq; 8-KN - Zargar; 9-KN - Karasoy; 10-KN - the city of Jizzakh; 11-12-KN - Qli collector.

\section{HE MAIN FINDINGS AND RESULTS}

The middle reaches of the Sangzor River flow through the points from Sutlibulak village to Zargar village. That is:

V-observation point-Sutlibulak village

VI-observation point-Odamali village

VII-observation point-Chuvullak village

Observation point VIII-Zargar village.

The algae flora of the Sangzor River was studied during 2009-2017, and algal observations were made in four seasons of the year and algal samples were collected from the identified observation points.

During the research, more than 340 algal samples were collected from the upper, middle and lower reaches of the Sangzor River. Of these, 130 are phytoplankton, 130 are phytobenthos, and 80 are periphyton.

During the collection of algal samples, water and air temperature, river width and depth, water clarity and color, flow rate, as well as sources of pollution, the amount of oxygen in the water and the $\mathrm{pH}$ of the water were taken into account.

In the process of collecting samples of plankton organisms, plankton nets № 76, 78 were used. A scalpel, ruler, and water batometer were used to collect benthos and periphyton algae samples..

The algae of the river, which grow on the concrete of the walls, adhere to the rocks on the shore and on the surface of the water, formed a fibrous, green, bluegreen, brown film, directly by hand, algae in the area of $1-10 \mathrm{~cm}$ are scraped with a scalpel and knife. The length of the samples taken was measured at this point using a ruler.

The samples were placed in glass jars, covered with 34 drops of $4 \%$ formalin solution and fixed (canned). Some of the samples were brought to the laboratory alive without fixation. Preparations were prepared from algal samples brought in the laboratory and the species composition of algae was determined under a microscope.

In the process of microscopic examination of algae, a scale of 1-9 was used to determine the dominant and subdominant types of algae in determining their degree of occurrence [3]. In the process:

1 point - one piece

2 points - very low

3 points - little

5 points - more 
7 points - a lot

9 points - equivalent to many such levels

Classes of algae according to the saprobility zone and quality O.A. Alekin [1, 2], I.N. Jukinsky et al. [4]. The temperature of water and air was determined using a mercury thermometer (0.1), the amount of hydrogen ions in the water was determined using a set of Michaelson indicator (litmus) papers and universal indicators. The clarity of the water was measured using a Sekki disk, and the flow rate was measured using a foam with a stopwatch. In determining the physicochemical composition of river water was based on the methods of hydrochemical analysis [5] and the data of the Ecological Committee of Jizzakh region.

The role of environmental factors in the growth, development and distribution of all plants distributed in nature is enormous. Under the influence of a combination of environmental conditions (light, heat, substrate, chemical composition of water, etc.), algae form various associations or cenoses. In this case, each association will have its own permanent types.

Many natural factors influence the distribution of algae in different biocenoses and the abundance or scarcity of species in their composition.

During the seasons, the water temperature in the Sangzor River varies from $+2^{\circ}$ to $+28^{\circ} \mathrm{C}$, and the air temperature from $0^{\circ}$ to $37^{\circ} \mathrm{C}$. The mineralization of water varies from fresh to brackish. Along the stream, the clarity of the river is clear above the water, the bottom of the water is visible (only in the spring the clarity of the water above was $2-8 \mathrm{~cm}$ ), and below 2 $5-8-25 \mathrm{~cm}$, the flow velocity is $0.5-1.7 \mathrm{~m} / \mathrm{sec}$., the depth is from 0.3-0.7 $\mathrm{m}$ to the Qli collector and from 3$4.8 \mathrm{~m}$ (in winter it flows very slowly in the territory of Jizzakh city, sometimes it does not flow).

The water of the Sangzor River is composed of various chemical compounds. The amount and composition of chemical compounds are constantly increasing along the river flow. The chemical composition and color of the water will change due to the construction of the Tuyatortar canal in the village of Karasay, the addition of Takursay collector ditch water to the Qli collector, and others.

During the study of the algae flora of the Sangzor River, 522 species and varieties of algae were identified, consisting of 7 divisions, 15 classes, 24 orders, 47 families, 100 genera. These, Cyanophyta56, Rhodophyta-2, Xanthopyta-7, Chrysophyta-2, Bacillariophyta-355, Euglenophyta-15, Chloro phyta-85 were analyzed [6, 7].

Of these, 351 species and subspecies (247 species, 92 variations, 12 forms) were found to be distributed along the middle reaches of the river (Table 1 ).

Among the algae, Bacillariophyta (154 species, 82 variations, 5 forms), Chlorophyta (54 species, 8 variations, 1 form), Cyanophyta (28 species, 6 forms) are leading in terms of species and species diversity.

There is Stephanodiscus subsalsus, Diatoma vulgare from the Bacillariophyta division breve, Opephora Martyi, Fragilaria virescens var. elliptica, Stauroneis anceps, Navicula brekkaensis, Pinnularia interrupta f.minutissima, Caloneis nubicola. baicalensis, Amphora coffeaeformis var. angularis, Cymatopleura elliptica, Surirella bifida, etc.

From the Chlorophyta section in the middle of the river Pandora charkoviensis, Chodatella longiseta, Chlorhormidium floating, and Chaetophora elegant, Zygnema torment, Spirogyra inflated, Actinotaenium to a truncate, Cosmoastrum kokonoricum, Cosmoeladium pulchellum, Cyanophyta бўлимининг Synechocystis sallensis, Aphanothese with microscopic, Cyanodictyon endophytic, Gloeocapsa tenacious, Eucapsis minutes, Nostoc sky blue-Spirulina flovovirens, bacterium ercegovici were found to be widespread.

Table 1

Algae scattered in the middle part of the Sangzor River

\begin{tabular}{|c|c|r|r|r|r|}
\hline $\begin{array}{c}\text { Algae } \\
\text { Department }\end{array}$ & $\begin{array}{r}\text { Tot } \\
\text { al }\end{array}$ & e & $\begin{array}{r}\text { Typ } \\
\text { iation }\end{array}$ & $\begin{array}{c}\text { Fo } \\
\text { rm }\end{array}$ \\
\hline & Cyanophyta & 34 & 28 & - & 6 \\
\hline Rhodophyta & 1 & 1 & - & - \\
\hline & Xanthophyta & - & - & - & - \\
\hline & Chrysophyta & 2 & 2 & - & - \\
\hline & Bacillariophyta & 24 & 154 & 82 & 5 \\
\hline & 1 & & & - \\
\hline
\end{tabular}




\begin{tabular}{|c|r|r|r|r|}
\hline Chlorophyta & 63 & 54 & 8 & 1 \\
\hline Total: & 35 & 247 & 92 & 12 \\
& 1 & & & \\
\hline
\end{tabular}

There are Trachelomonas asymmetrica, T.cylindrica, T. volvocina of the Euglenophyta division. punctata, Euglena clara, E. matvienkoi, Chromulina rosanoffii and Chrysococcus cordiformis species from the Chrysophyta division. Antithamnion boreale type of Rhodophyta division was identified.

Natural water bodies contain various chemical compounds. But this compound is a very small amount relative to the volume of water.

An important component of water is mineral salts or biogenic elements (dissolved and insoluble organic matter), accumulated organo-mineral compounds. The chemical properties of river water depend on its sources of saturation and the hydrobiological regime that occurs in it. The conditions of the catchment area and local climatic factors play an important role in assessing the chemical condition of the river.

Minerals necessary for the life of algae are nitrogen and phosphorus salts. The small amount of these salts in the river causes great damage to the development of algae. In addition, algae need iron, calcium, magnesium, potassium, sulfur, silicon and other trace elements for life.

The need for iron and calcium is not the same in all algae. Sometimes when the amount of calcium salts in the water increases, some species disappear. In contrast, diatoms, desmidium, ulotrix, draparnaldia, and other algae have high iron requirements and thrive in water containing 1-2 mg of $\mathrm{Fe} 2 \mathrm{O} 3$ per liter. Sladophora grows easily in water containing $25 \mathrm{mg} / \mathrm{I}$ calcium and $0.5 \mathrm{mg} / \mathrm{I}$ iron. The amount of iron in the Sangzor River is observed to be in the range of 0.1-0.6 $\mathrm{mg} / \mathrm{I}$ and in the river Cladophora fracta, C. glomerata, Draparnaldiella simplex, Ulothrix moniliformis, U. mucosa, U. tenerrima, U. zonata, U. zonata var. attenuated, $U$. zonata var. pectinalis such species.

Silicon is one of the essential elements for the cooling of diatom algae, and the element calcium is an important biological substance that is found in the cell membrane. When the amount of silicon in the water is $5 \mathrm{mg}$, the cell of the diatom algae divides, but when its amount reaches $0.5 \mathrm{mg}$, the cell stops growing. Diatom algae on the Sangzor River Cyclotella covers, C.operculata ssp. mesoleia, Meridion circular, diatoms issue Fragilaria construens var. subsalina, Synedra panels ssp. a small, COCCONEIS fact, nobody remembers var. diminished Achnanthes lanceolata $f$. head, boat Hungarian ssp. lueneburgensis, Gyrosigma scalproides ssp. exceptional Cymbella equal, Gomphonema hemmed Nitella fiber ssp. tennirostris, linear Synedra such species.

While the main reason for the rapid development of diatoms in spring and autumn is an increase in the amount of essential nutrients with heat, the latter is also associated with an increase in silicon salts.

\section{ONCLUSION}

In conclusion, the distribution of algae detected in the Sangzor River was found to depend on the mineralization of the water and the amount of suspended particles in the water as the number of stenogalin species increases in the upper reaches and the number of species in the freshwater watersheds decreases.

During the study of the algae flora of the Sangzor River, 522 species and varieties of algae were identified in 7 sections, 15 classes, 24 orders, 47 families, 100 genera, of which 351 species and varieties (247 species, 92 variations, 12 forms) along the middle reaches of the river. was found to be scattered. Among the algae, Bacillariophyta (154 species, 82 variations, 5 forms), Chlorophyta (54 species, 8 variations, 1 form), Cyanophyta (28 species, 6 forms) are leading in terms of species and species diversity.

\section{EFERENCES}

1. Alekin O.A. Fundamentals of Hydrochemistry. - L. Gidrometeoizdat, 1970. - P. 443.

2. Alekin O.A., Semenova A.D., Skopintseva B.A. Manual for the chemical analysis of land waters - L. Gidrometeoizdat, 1973 - P. 270.

3. Rudina L.O. Keys to freshwater algae of the Ukrainian USSR. Issue 7. (ConjugatesConjugatophyceae Part 3 Zignemovy Zygnematales). - Kiev: naukova dumka, 1988. - P. 204.

4. Jukinsky V.N., Oksiyuk O.P., Oleinik G.N., Koshelova S.I. Principles and experience of constructing an ecological classification of the quality of land surface waters // Hydrobiol magazine. - Kiev. 1981. XVII. № 12. - P. 38 - 49.

5. Shishkina L.A. Hydrochemistry. Textbook for hydrometeorological technical schools - London: Gidrometeoizdat, 1974. -P. 286.

6. Ismatova Z.A. Seasonal development of aquatic of the class Chlorophyta and their distribution on the 
current of the river Sangzar // The Tenth International Conference on Biology and Medical Sciences. 5th June 2016. Austria, Vienna. -P.86 90.

7. Ismatova Z.A. Floristic and systematic analysis of the composition of algoflora of the Sangzar River // International Journal of Advanced Science and Technology, Vol. 29, № 8. 2020. pp. 3449 - 3453.

8. Go'dalov, M. R. (2014). Nature of Jizzakh region and its protection.-T.:". Science and technology.

9. Go'dalov, M. Impact of the Aydar-Arnasay lake system on landscapes. ffd PhD science. dar. present to receive. diss.

10. Orzikulova, G., \& Nematovich, N. O. (2020). Right in ancient world history. Asian Journal of Multidimensional Research (AJMR), 9(3), 144-148. 